\title{
Smoking is a Strong Independent Predictor of Acute Coronary Syndrome Among Patients with Coronary Artery Ectasia
}

\author{
Koroner Arter Ektazisi Olan Hastalarda Akut Koroner Sendromun Güçlü Bağımsız Bir \\ Öngördürücüsü: Sigara
}

\author{
(1) Ahmet Gürdal, (D) Serhat Sığırcı, (1) Kadriye Orta Kılıçkesmez \\ University of Health Sciences Turkey, Șișli Hamidiye Etfal Training and Research Hospital, Clinic of Cardiology, İstanbul, Turkey
}

\begin{abstract}
Introduction: The independent relationship between smoking and Acute Coronary syndrome (ACS), among other risk factors, was investigated in patients with ectasic coronary arteries.

Methods: Between June 2015 and August 2018, 10.320 coronary angiography processes performed in our clinic were analyzed retrospectively. Coronary artery ectasia (CAE) was defined as the enlargement of a coronary artery to 1.5 times or more than that of the local or adjacent normal coronary artery segment. Patients were divided into two groups with (group 1) and without ACS (group 2). The two groups were compared in terms of demographic characteristics, laboratory findings and major risk factors such as hypertension, diabetes mellitus (DM) and smoking. Multivariate logistic regression analysis was used to evaluate independent predictors of ACS in patients with CAE.

Results: There were 189 (1.8\%) patients with CAE and 143 (76\%) of them were male. Of the patients, 107 (57\%) were smoking, $106(56 \%)$ had hypertension and $43(22 \%)$ had DM. One hundred two (54\%) of the patients presented with ACS. There was no significant difference between the groups in terms of hypertension, DM and basic laboratory characteristics. Smoking rate was significantly higher in the ACS group (66\% and 34\%, $p=0.001$ ). In multivariate logistic regression analysis, when hypertension, DM, age, gender and smoking were evaluated together, smoking was strongly predictive of ACS in patients with ectasic coronary artery [odds ratio: 2.34, (95\% confidence interval), 1.093-4.983, $p=0.028]$.
\end{abstract}

Conclusion: When the factors that play an important role in the etiology of ACS are evaluated together in patients with CAE, smoking predicts ACS strongly and independently.

Keywords: Acute coronary syndrome, coronary arteria ectasia, coronary artery disease, smoking

\section{öZ}

Amaç: Ektazik koroner arterlere sahip hastalarda, diğer önemli risk faktörlerinin yanında sigara ile Akut Koroner sendrom (AKS) arasındaki bağımsız ilișki araștıııldı.

Yöntemler: Kliniğimizde Haziran 2015-Ağustos 2018 tarihleri arasında yapılan 10.320 adet koroner anjiyografi geriye doğru analiz edildi. Koroner arter ektazisi, koroner arterin bölgesel ya da komşu normal koroner arter segmentinin 1,5 katı veya daha fazlası olacak șekilde genișlemesi olarak tanımlandı. Hastalar AKS olan ve olmayan olarak iki gruba ayrıldı. İki grup demografik özellikler, laboratuvar bulguları ve hipertansiyon, diabetes mellitus (DM) ve sigara gibi majör risk faktörleri açısından karşılaştırıldı. Çok değişkenli lojistik regresyon analizi ile ektazik koroner arterlere sahip hastalarda AKS'yi bağımsız öngördürücü risk faktörleri değerlendirildi.

Bulgular: Yüz kırk üçü erkek (\%76), toplam 189 adet $(\% 1,8)$ koroner ektaziye sahip hasta saptandı. Ektazi görülen hastaların 106'sı (\%56) hipertansiyon, 43'ü (\%22) DM tanılıydı ve 107 'si (\%57) sigara içmekteydi. Hastalardan 102'si (\%54) AKS kliniği ile başvurdu. AKS olan (grup 1), AKS olmayan (grup 2) ile karşılaştırıldığında hipertansiyon, DM ve temel laboratuvar özellikleri açııından gruplar arasında anlamlı fark yoktu. Grup 1 daha genç ( $58 \pm 13$ ve $63 \pm 10, p=0,016)$ ve erkek (\%82 ve $\% 67$, $p=0,027)$ ağırlıkııdı. AKS olan grupta sigara içme oranı anlamlı olarak yüksekti (\%66 ve \%34, $p=0,001)$. Çok değişkenli lojistik regresyon analizinde hipertansiyon, DM, yaş, cinsiyet ve sigara birlikte değerlendirildiğinde, sigaranın ektazik koroner arterli hastalarda AKS'yi güçlü bağımsız bir şekilde öngördürdüğü saptandı [odds ratio: 2.34, (\%95 güven aralığı), 1.093-4.983, $\mathrm{p}=0,028]$.

Sonuç: Ektazik koroner arterlere sahip hastalarda, AKS etiyolojisinde önemli rol oynayan etkenler birlikte değerlendirildiğinde, sigara AKS'yi güçlü ve bağımsız bir şekilde öngördürmektedir.

Anahtar Kelimeler: Akut koroner sendrom, koroner arter ektazisi, koroner arter hastalığı, sigara 


\section{Introduction}

The role of smoking in the development of coronary artery disease (CAD) has been demonstrated in many studies (1). Smoking is held responsible for approximately one third of the deaths caused by cardiovascular diseases (2). Smoking primarily damages the cardiovascular system by increasing oxidative stress and inflammation, causing vasoconstriction and platelet dysfunction (3). It is known that major cardiac events and death are more common in those who have CAD and continue to smoke, but this risk is reduced by $40 \%$ in those who quit smoking (4).

Coronary artery ectasia (CAE) has been defined as the expansion of the coronary artery regionally or commonly to be 1.5 times or more of the adjacent normal coronary artery segment (5). Although CAE is often seen with CAD, it can also be detected as isolated. Isolated CAE is more rarely seen with a frequency of $0.1 \%$ to $0.79 \%$ among patients undergoing coronary angiography (6). When the etiology of CAE is examined, it is most frequently associated with atherosclerosis. Inflammation, oxidative stress, congenital anomalies, collagen tissue diseases and connective tissue diseases are among other causes (7).

In studies performed, it has been shown that ectasia leads to slow flow, thrombus formation and vasospasm in the coronary arteries, and perfusion defects can be observed in the myocardium due to the slow flow and possible microembolism $(8,9)$. Coronary ectasias are mostly seen with CAD. Although there is no significant stenosis in the coronary arteries, dissection and thrombus occurring in the ectasia region can cause acute coronary syndrome (ACS) (10).

Many studies and researches have shown that smoking causes early atherosclerosis with a negative effect on the vascular wall, especially endothelial dysfunction, in early stage. Smoking causes coronary events by increasing inflammation in the vascular wall, causing vasospasm and leading to tendency to thrombosis. In ectasic coronaries, besides atherosclerosis, the frequency of coronary events increases due to negative factors such as slow flow, inflammation, dissection etc. (11). In our study, the independent relationship between smoking and ACS, among other important risk factors, was investigated in patients with ectasic coronary arteries.

\section{Methods}

Ten thousand three hundred twenty coronary angiographies performed between June 2015 and August 2018 in our clinic were analyzed retrospectively. In accordance with the angiographic definition of Hartnell et al. (5), CAE was defined as an expansion of the coronary artery diameter by 1.5 times or more than the adjacent normal segment. Regional or diffuse enlargement without significant coronary artery stenosis was considered as isolated ectasia. The presence of more than 50\% narrowing in the coronary artery was considered as important obstruction and CAD. Patients presenting with ST segment elevation myocardial infarction (STEMI), non-ST segment elevation myocardial infarction (NSTEMI) and unstable angina pectoris (USAP) clinic were defined as ACS. The patients were divided into two groups, with and without ACS. The two groups were compared in terms of demographic features, laboratory findings, and major risk factors such as hypertension, diabetes mellitus (DM) and smoking. Risk factors predicting ACS were evaluated by multivariate logistic regression analysis in patients with ectasic coronary arteries. The study was approved by the ethics committee of University of Health Sciences Turkey, Şişli Hamidiye Etfal Education and Research Hospital (2534 / 17.09.2019). As it was a retrospective study, consent was not obtained from the patients.

\section{Statistical analysis}

SPSS Windows version 20 statistics program (SPSS, Inc. Chicago, IL, USA) was used to evaluate the data. Continuous variables were expressed as mean \pm standard deviation and categorical variables as percentage values. The normal distribution analysis of the data was done with the Kolmogorov-Smirnov test. Independent t-test was used to compare continuous variables with normal distribution, and Mann-Whitney $U$ test was used to compare continuous variables without normal distribution. Categorical variables were evaluated by the chi-square test. Pearson and Spearman correlation analysis was used for correlation analysis. The relationship between two variables was evaluated by univariate and multivariate logistic regression. $P$ value $\leq 0.05$ was considered significant.

\section{Results}

Ten thousand three hundred twenty coronary angiographies performed between June 2015 and August 2018 were analyzed retrospectively and $189(1.8 \%)$ patients with coronary ectasia were detected. One hundred fourty three of the patients with ectasia were male (76\%). While 107 (57\%) of the patients were smoking, 106 (56\%) were diagnosed with hypertension and $43(22 \%)$ with DM. The number of dyslipidemic patients was 96 (51\%) (Table 1).

While 43 (23\%) of 102 (54\%) patients presenting with ACS had ST STEMI, 59 (31\%) had NSTEMI or USAP (Table 1). Of the patients admitted with ACS, CAD that did not cause significant stenosis was detected in 23

\begin{tabular}{|c|c|}
\hline Clinical features & Ectasia $(\mathrm{N}=189)$ \\
\hline Age & $61 \pm 12$ \\
\hline Male & $143(76 \%)$ \\
\hline Smoking & $107(57 \%)$ \\
\hline Hypertension & $106(56 \%)$ \\
\hline Diabetes mellitus & $43(22 \%)$ \\
\hline $\mathrm{EF}(\%)$ & $52 \pm 10$ \\
\hline Acute coronary syndrome & $102(54 \%)$ \\
\hline STEMI & $43(23 \%)$ \\
\hline NSTEMI/USAP & $59(31 \%)$ \\
\hline Glucose (g/L) & $136 \pm 64$ \\
\hline Hemoglobin $(\mathrm{g} / \mathrm{dL})$ & $13.8 \pm 2.1$ \\
\hline Leucocyte (g/dL) & $9.6 \pm 3.7$ \\
\hline Platelet $\left(10^{3} / \mu \mathrm{L}\right)$ & $228 \pm 59$ \\
\hline Total cholesterol(mg/dL) & $193 \pm 57$ \\
\hline HDL-k (mg/dL) & $40 \pm 9$ \\
\hline LDL-k (mg/dL) & $123 \pm 54$ \\
\hline Triglyceride (mg/dL) & $161 \pm 96$ \\
\hline Creatinine $(\mathrm{mg} / \mathrm{dL})$ & $1.1 \pm 0.9$ \\
\hline
\end{tabular}

EF: ejection fraction, STEMI: ST segment elevation myocardial infarction, NSTEMI: non-ST segment elevation myocardial infarction, USAP: unstable angina pectoris 
patients, single vascular disease in 35 patients, two vascular diseases in 23 patients, and three vascular diseases in 21 patients. Sixty eight of the patients (36\%) had isolated ectasia without significant coronary stenosis.

When patients with ACS (group 1) and without ACS (group 2) were compared, there was no significant difference between the groups in terms of hypertension, DM, platelet count, lipid values and creatinine. While hemoglobin was slightly high in group $1(14 \pm 2.1$ and $13.5 \pm 2.0$ $p=0.040$ ), the leukocyte count was significantly higher in group 1 , as expected. $(10.7 \pm 4.2$ and $8.3 \pm 2.3 p=0.001)$. Group 1 was younger (58 \pm 13 and $63 \pm 10, p=0.016)$ and mostly male ( $82 \%$ and $67 \%, p=0.027)$. Smoking rate was significantly higher in the group with ACS $(66 \%$ and $34 \%, p=0.001)$. Ejection fraction was detected to be slightly lower in group 1 ( $50 \pm 10$ and $54 \pm 10 p=0.03$ ). (Table 2 ). In the multivariate logistic regression analysis, when hypertension, DM, age, gender and cigarette were evaluated together, it was found that smoking predicted ACS strongly and independently in patients with ectasic coronary arteries [odds ratio:2.34, (95\% confidence interval), 1.093-4.983, $p=0.028$ ] (Table 3).

\section{Discussion}

Although smoking is known to be a risk factor for ACS, its role and importance have not been clearly demonstrated in patients with ectasic

\begin{tabular}{|c|c|c|c|}
\hline & $\operatorname{ACS}(+) N=102$ & $\operatorname{ACS}(-) \mathrm{N}=87$ & p \\
\hline Age & $58 \pm 13$ & $63 \pm 10$ & 0.016 \\
\hline Gender (male) & $84(82 \%)$ & $59(67 \%)$ & 0.027 \\
\hline Smoking & $70(66 \%)$ & 37 (34\%) & 0.001 \\
\hline Hypertension & $56(53 \%)$ & $50(47 \%)$ & 0.723 \\
\hline Diabetes mellitus & $26(60 \%)$ & $17(40 \%)$ & 0.331 \\
\hline $\mathrm{EF}(\%)$ & $50 \pm 10$ & $54 \pm 10$ & 0.003 \\
\hline Glucose (g/L) & $151 \pm 71$ & $118 \pm 50$ & 0.001 \\
\hline Hemoglobin (g/dL) & $14 \pm 2.1$ & $13.5 \pm 2$ & 0.040 \\
\hline Leukocyte $\left(10^{3} / \mu \mathrm{L}\right)$ & $10.7 \pm 4.2$ & $8.3 \pm 2.3$ & 0.001 \\
\hline Platelet $\left(10^{3} / \mathrm{L}\right)$ & $230 \pm 55$ & $226 \pm 63$ & 0.460 \\
\hline T. Cholesterol(mg/dl) & $196 \pm 68.7$ & $189 \pm 40.9$ & 0.870 \\
\hline HDL-k (mg/dL) & $39.5 \pm 7.7$ & $41 \pm 9$ & 0.250 \\
\hline LDL-k (mg/dL) & $127 \pm 65$ & $119 \pm 35$ & 0.757 \\
\hline Triglyceride (mg/dL) & $170 \pm 119$ & $150 \pm 57$ & 0.776 \\
\hline Creatinine (mg/dL) & $1.2 \pm 1.1$ & $1.0 \pm 0.7$ & 0.369 \\
\hline
\end{tabular}

ACS: acute coronary syndrome, EF: ejection fraction, T. Cholesterol: total cholesterol

Table 3. Multivariate logistic regression analysis showing acute coronary syndrome predictive independent variables

\begin{tabular}{|l|l|l|}
\hline Variables & Multivariate OR (95\% CI) & p \\
\hline Age & $0.981(0.956-1.008)$ & 0.164 \\
\hline Gender & $0.885(0.379-2.065)$ & 0.777 \\
\hline Smoking & $2.334(1.093-4.983)$ & 0.028 \\
\hline Hypertension & $1.014(0.512-1.953)$ & 0.969 \\
\hline Diabetes mellitus & $1.384(0.629-3.044)$ & 0.419 \\
\hline OR: odds ratio, Cl: confidence interval & \\
\hline
\end{tabular}

coronary artery when evaluated with other known risk factors. In the literature review, it was observed that smoking was not discussed separately in terms of ACS in patients with ectasic coronary disease. In our study, it was found that smoking predicted ACS strongly and independently in this patient group.

Cardiovascular diseases are the major cause of mortality and morbidity in the world (12). In epidemiological studies, most of the cardiovascular risk consists of dyslipidemia, smoking, hypertension, DM, obesity, unbalanced diet and immobile life. While age, gender, family history at an early age, and race are the causes that cannot be modified, dyslipidemia, hypertension, smoking and DM are modifiable causes (13).

The frequency of CAE, which is detected in coronary angiographies performed for the suspicion of CAD, varies between $0.3-4.9 \%$ (14). In our study that we performed by analyzing the patients in our clinic, the frequency of ectasic coronary artery was found to be $1.8 \%$. In addition to studies reporting that CAE is observed in similar rates in women and men (15), it was found more frequently in men in some studies (5). According to the The Effect of Potentially Modifiable Risk Factors Associated with Myocardial Infarction (INTERHEART) case-control study, ACS is more common in young men (16). In our study, $76 \%$ of patients with CAE and $82 \%$ of patients with ACS were male.

Hypertension is responsible for 35\% of all atherosclerotic cardiovascular events. Hypertension increases the risk of ACS 2-3 times in men and women (17). In a study by Markis et al. (18), hypertension was found to be more frequent in patients with ectasia and it was suggested that hypertension may play a role in the pathogenesis of coronary ectasia by accelerating the destruction of the media layer. In the study conducted by Sultana R. et al. (19), 55\% of patients were diagnosed with hypertension, and similarly, in our study, $56 \%$ of patients had hypertension, and there was no significant difference in terms of hypertension between those with and without ACS.

DM is an independent risk factor for ACS, increasing the risk in men and women two and four times, respectively. According to the INTERHEART study, the prevalence of DM in patients with ACS has been shown to be $16 \%$ in men and $26 \%$ in women (16).

In the study of Sultana R. et al. (19), while $26 \%$ of patients with CAE were found to have DM, $22 \%$ of the patients were diagnosed with DM and no significant difference was found in terms of DM between those with and without ACS.

Atheromatous plaques are found on the basis of ACS. Dyslipidemia constitutes the basis of atherosclerosis. Although LDL is the primary lipid risk factor, other lipid parameters such as low HDL values and high triglyceride also pose a risk for CAD. Low HDL values, high triglycerides and high LDL values play an important role in the formation of atherogenic dyslipidemia (20). Many studies have demonstrated that each of these lipid parameters are independent risk factors for CAD $(21,22)$. Atherosclerosis plays a major role in the etiology of CAE. In the pathological examination of ectasic coronary arteries, cholesterol crystals, calcification and fibrosis, intima and media destruction, lipid accumulation were found and these histological changes were observed to be the same as atherosclerotic process. (5). In a study by Sultana R. 
et al. (19), dyslipidemia was reported in 58\% of patients with CAE, and similarly in our study, $51 \%$ of patients had dyslipidemia. In our study, occlusive CAD was detected in $64 \%$ of patients with CAE, while $54 \%$ of patients presented with ACS. There was no difference in lipid parameters between the groups with and without ACS.

A strong relationship has been demonstrated between the number of cigarettes smoked and coronary heart disease in all groups independent of gender, age and race (23). Smoking increases the risk two to three times and increases the risk by interacting with other risk factors. The risk of myocardial infarction and cardiac death in smokers was found to be 2.7 times higher in males and 4.7 times higher in females compared to the non-smokers, and smoking is the most important preventable cause of mortality (24). The role and mechanism of smoking in atherosclerosis has been demonstrated by many studies. Smoking is known to initiate endothelial dysfunction and the inflammatory process in the endothelium. It has been shown in studies that cigarette smoke impairs vascular endothelial integrity and increases platelet activation and accelerates the entry of leukocytes into atherosclerotic lesions (25). In studies conducted, no difference was observed between patients with normal coronary artery structure and patients with CAE in terms of smoking. In the study of Yılmaz H. et al. (26), no significant difference was reported in patients with CAE in terms of gender, age, hyperlipidemia, DM and smoking compared to the control group. According to the Turkish Adult Risk Factor (TEKHARF) study (27), while the rate of smoking was around $30 \%$, more than half of the patients were smoking in our study group. The rate of smoking was higher in patients presenting with ACS compared to the other group (66\% vs. $34 \% \%)$. In multivariate regression analysis, it was found that smoking predicted ACS strongly and independently in patients with CAE.

\section{Conclusion}

Coronary artery ectasia is an important cause of mortality and morbidity, although it is not common in the community. In CAE, where many factors especially atherosclerosis play a role in the etiology, ACS can develop with or without obstructive CAD. Hypertension, DM, age, gender, dyslipidemia and smoking, which have an important place in the etiology of ACS, are also important in patients with CAE. In our study, it was found that smoking, which has an important place among these risk factors in patients with CAE, predicts ACS strongly and independently. Therefore, we think that smoking should be prevented in patients with CAE and rehabilitation for this issue should be given due importance for patients.

\section{Ethics}

Ethics Committee Approval: The study was approved by the ethics committee of University of Health Sciences Turkey, Şişli Hamidiye Etfal Education and Research Hospital (2534 / 17.09.2019).

Informed Consent: Retrospective study.

Peer-review: Internally peer-reviewed.

Authorship Contributions: Surgical and Medical Practices - A.G., K.O.K.; Concept - A.G., Design - A.G., S.S.; Data Collection or Processing - A.G., S.S.; Analysis or Interpretation - A.G., K.O.K.; Literature Search - S.S.; Writing - A.G.
Conflict of Interest: No conflict of interest was declared by the authors.

Financial Disclosure: The authors declared that this study received no financial support.

\section{References}

1. Ambrose JA, Barua RS. The pathophysiology of cigarette smoking and cardiovascular disease: an update. J Am Coll Cardiol 2004; 43: 1731-37.

2. CDC. Smoking-attributable mortality, years of potential life lost, and productivity losses—United States, 2000-2004. MMWR 2008; 57:1226-8.

3. Talukder MAH, Johnson WM, Varadharaj S, Lian J, Kearns PN, El-Mahdy MA, et al. Chronic cigarette smoking causes hypertension, increased oxidative stress, impaired NO bioavailability, endothelial dysfunction, and cardiac remodeling in mice. Am J Physiol Heart Circ Physiol 2011; 300: H388-96.

4. Shah AM, Pfeffer MA, Hartley LH, Moyé LA, Gersh BJ, Rutherford JD, et al. Risk of all-cause mortality, recurrent myocardial infarction, and heart failure hospitalization associated with smoking status following myocardial infarction with left ventricular dysfunction. Am J Cardiol 2010; 106: 911-6.

5. Hartnell GG, Parnell BM, Pridie RB. Coronary artery ectasia. Its prevalence and clinical significance in 4993 patients. Br Heart J 1985; 54: 392-5.

6. Al-Harthi SS, Nouh MS, Arafa M, al-Nozha M: Aneurysmal dilatation of the coronary arteries: diagnostic patterns and clinical significance. Int J Cardiol 1991; 30: 191-4.

7. Sayin T, Doven O, Berkalp B, Akyurek O, Gulec S, Oral D. Exercise-induced myocardial ischemia in patients with coronary artery ectasia without obstructive coronary artery disease. Int J of Cardiol 2001; 78: 143-9.

8. Papadakis MC, Manginas A, Cotileas P, Demopoulos V, Voudris V, Pavlides G, et al. Documentation of slow coronary flow by the TIMI frame count in patients with coronary ectasia. Am J Cardiol 2001; 88: 1030-2.

9. Kruger D, Stierle U, Herrmann G, Simon R, Sheikhzadeh A. Exercise-induced myocardial ischemia in isolated coronary artery ectasias and aneurysms ("dilated coronopathy"). J Am Coll Cardiol 1999; 34: 1461-70.

10. Mattern AL, Baker WP, McHale JJ, Lee DE. Congenital coronary aneurysms with angina pectoris and myocardial infarction treated with saphenous vein bypass graft. Am J Cardiol 1972; 30: 906-9.

11. Barbara Messner, David Bernhard. Smoking and Cardiovascular Disease Mechanisms of Endothelial Dysfunction and Early Atherogenesis. Arterioscler Thromb Vasc Biol 2014; 34: 509-15.

12. Naghavi M, Wang H, Lozano R, Davis A, Liang X, Zhou M, et al. Global, regional, and national age-sex specific all-cause and cause-specific mortality for 240 causes of death, 1990-2013: a systematic analysis for the Global Burden of Disease Study 2013. Lancet 2015; 385: 117-71.

13. Yusuf S, Hawken S, Ounpuu S, Dans T, Avezum A, Lanas F, et al. Effect of modifiable risk factors associated with myocardial infarction in 52 countries (the INTERHEART study): case-control study. Lancet 2004; 364: 937-52.

14. Oliveros RA, Falsetti HL, Carroll RJ, Heinle RA, Ryan GF. Atherosclerotic coronary artery aneurysm. Report of five cases and review of literature. Arch Intern Med 1974; 134: 1072-6.

15. Demopoulos VP, Olympios CD, Fakiolas CN, Pissimissis EG, Economides NM, Adamopoulou $\mathrm{E}$, et al. The natural history of aneurysmal coronary artery disease. Heart 1997; 78: 136-41.

16. Anand SS, Islam S, Rosengren A, Franzosi MG, Steyn K, Yusufali AH, et al. Risk Factors for Myocardial Infarction in Women and Men: Insights from the INTERHEART study. Eur Heart J 2008; 29: 932-40.

17. Stratton JR, Chandler WL, Schwartz RS, Cerqueira MD, Levy WC, Kahn SE et al. Effects of Physical Conditioning on Fibrinolytic Variables and Fibrinogen in Young and Old Healthy Adults. Circulation 1991; 83: 1692-7. 
18. Markis JE, Joffe CD, Cohn PF, Feen DJ, Herman MV, Gorlin R. Clinical significance of coronary arterial ectasia. Am J Cardiol 1976; 37: 217-22.

19. Sultana R, Sultana N, Ishaq M, Samad A. The prevalence and clinical profile of angiographic coronary ectasia.J Pak Med Assoc 2011; 61: 372-5.

20. Grundy SM. Hypertriglyseridemia, atherogenic dyslipidemia, and the metabolic syndrome. Am J Cardiol 1998; 81: 18-25.

21. Assmann G, Schulte H, Funke $H$, von Eckardstein A. The emergence of triglyserides as a significiant independent risk factor in coronary artery disease. Eur Heart J 1998; 19: 8-14.

22. Hokanson JE, Austin MA. Plasma triglyseride level as a risk factor for cardiovascular disease independent of highdensity lipoprotein cholesterol level: a meta-analysis of population-based prospective studies. J Cardiovasc Risk 1996; 3: 213-9.

23. US Department of Health and Human Services. The Health Consequences of Smoking: Cardiovascular Disease_A Report of the Surgeon General.
Washington, DC: Office of Smoking and Health, US government Printing Office; 1983.

24. U.S. Department of Health and Human Services. The Health Consequences of Smoking: Cardiovascular Disease. A Report of the Surgeon General. Rockville (MD): U.S. Department of Health and Human Services, Public Health Service, Office on Smoking and Health; 1983. DHHS Publication No. (PHS) 84-50204.

25. Hurst's The Heart. Valentin Fuster, R. Wayne Alexander, Robert O'Rourke. 10. Baskııının Türkçe çevirisi. And Danıșmanlık Eğitim Yayınclık ve Organizasyon Ltd. Ști. 1. Basım. 2002; 1065-1109.

26. Yilmaz H, Sayar N, Yilmaz M, Tangürek B, Cakmak N, Gürkan U, et al. Coronary artery ectasia: clinical and angiographical evaluation. Turk Kardiyol Dern Ars 2008; 36:5 30-5

27. TEKHARF; Oniki Yıllık İzleme Deneyimine Göre Türk Erişkinlerinde Kalp Sağlığı. Prof. Dr. Altan Onat, Prof. Dr. Vedat Sansoy, Prof. Dr. İnan Soydan, Prof. Dr. Lale Tokgözoğlu, Prof. Dr. Kamil Adalet. Argos Illetișim Hizmetleri Reklamcılık ve Ticaret Anonim Șirketi. Temmuz 2003, İstanbul. 